Esta publicación cientifica en formato digital es continuidad de la revista impresa ISSN-Versión Impresa 0798-1406 / ISSN-Versión on line 2542-3185Depósito legal pp
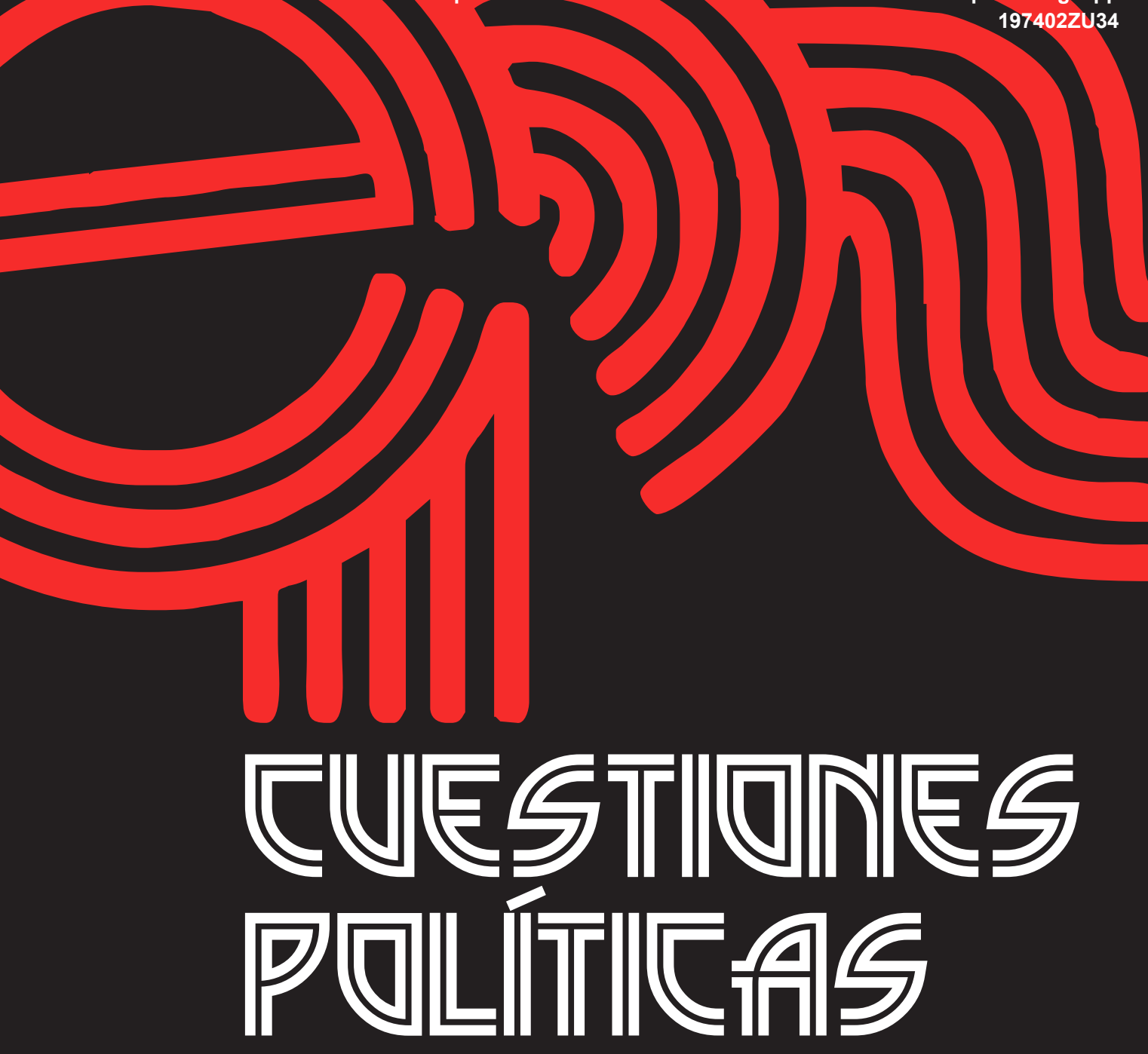

Instituto de Estudios Políticos y Derecho Público "Dr. Humberto J. La Roche" de la Facultad de Ciencias Jurídicas y Políticas de la Universidad del Zulia Maracaibo, Venezuela
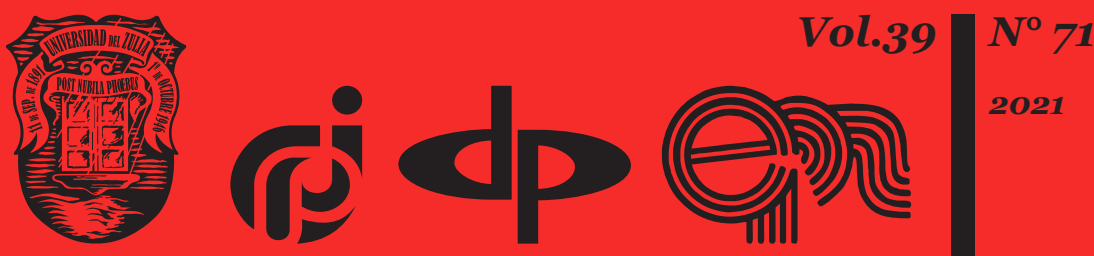


\title{
Legislative Provision of Standardisation of Armaments and Military Equipment Development: International Aspect
}

\author{
DOI: https://doi.org/10.46398/cuestpol.3971.04
}

\author{
Demian V.Smernytskyi * \\ Mykhailo Y. Aleksandrov ** \\ Vadym I. Prykhodko *** \\ Valerii M. Podoinitsyn **** \\ Malvina A. Bakal
}

\section{Abstract}

The aim of the study was to identify objectives and measures for expansion of the system of standards in Ukraine for the development of armaments and military equipment in the context of improving national defence capabilities. The following methods were used to achieve the aim set in the study: the method of direct observation, comparison, monitoring and analysis of the content of documents that provide standardisation of armaments and military equipment at the state and interstate levels. The key results of the study were: observation and comparison of the scope of regulations that ensure the standardisation of armaments and military equipment at the national level, as well as among NATO countries; comparison and distribution of powers of the competence of executive and supervisory bodies for the development and implementation of standards. Besides, the study provides a chart of the legal background for standardisation, and directly determines the sequential logical place of the stage of development of armaments and military equipment in the life cycle. Proposals are made at the end of the study on how to increase the effectiveness of legislative provision for the standardisation of armaments and military equipment.

* Doctor of Law, Senior Researcher, Assistant Director of the State Research Institute of the Ministry of Internal Affairs of Ukraine, 01011, Kyiv, Ukraine. ORCID ID: https://orcid.org/oooo-0001-60660324

** PhD in Law, Senior Researcher at the State Research Institute of the Ministry of Internal Affairs of Ukraine, 01011, Kyiv, Ukraine. ORCID ID: https://orcid.org/oooo-0001-9574-232X

*** PhD in Law, Senior Researcher at the Department of special transport, Research Laboratory of Special Transport and Uniforms, The State Research Institute of the Ministry of Internal Affairs of Ukraine, 01011, Kyiv, Ukraine. ORCID ID: https://orcid.org/oooo-0003-0452-6854

**** PhD in Law, Leading Researcher at the State Research Institute of the Ministry of Internal Affairs of Ukraine, 01011, Kyiv, Ukraine. ORCID ID: https://orcid.org/o0oo-0001-8874-1222

***** PhD in Law, Researcher at the State Research Institute of the Ministry of Internal Affairs of Ukraine, 01011, Kyiv, Ukraine. ORCID ID: https://orcid.org/oooo-0002-7623-890X 
Demian V. Smernytskyi, Mykhailo Y. Aleksandrov, Vadym I. Prykhodko, Valerï M.

Podoinitsyn y Malvina A. Bakal

Keywords: weapons; standardisation; standards; legislation; military equipment; Nato standards.

\section{Disposición legislativa de normalización de armamentos y desarrollo de equipos militares: Aspecto internacional}

\section{Resumen}

El objetivo del estudio fue identificar objetivos y medidas para la expansión del sistema de normas en Ucrania para el desarrollo de armamento y equipo militar en el contexto de la mejora de las capacidades de defensa nacional. Para lograr el objetivo planteado en el estudio se utilizaron los siguientes métodos: el método de observación directa, comparación, seguimiento y análisis del contenido de los documentos que proporcionan la estandarización de armamentos y equipos militares a nivel estatal e interestatal. Los resultados clave del estudio fueron: observación y comparación del alcance de las regulaciones que aseguran la estandarización de armamentos y equipos militares a nivel nacional, así como entre países de la OTAN; comparación y distribución de poderes de competencia de los órganos ejecutivos y supervisores para el desarrollo e implementación de normas. Además, el estudio proporciona un cuadro de los antecedentes legales para la estandarización y determina directamente el lugar lógico secuencial de la etapa de desarrollo de armamentos y equipos militares en el ciclo de vida. Se hacen propuestas al final del estudio sobre cómo aumentar la eficacia de la disposición legislativa para la estandarización de armamentos y equipos militares.

Palabras claves: armas estandarización; estándares; legislación; equipamiento militar; normas de la OTAN.

\section{Introduction}

Standards have existed for many millennia. For example, standards for measuring time, distance and weight were among the first types of standards created. As mankind progressed, the scope of standardisation grew.

Defence standards have emerged because of the need for proper performance, stability and reproduction, as well as the logistical benefits of military equipment (Eurolab, 2017). The current system of standardisation of development and production of weapons, ammunition and military 
equipment attracts attention not only in terms of co-ordination of compatibility of weapons by calibre, outfit by functionality and special equipment by purpose, but also because individual parts and elements of one defence product can be produced in different geolocations and countries. In this case, if the relevant standards are met, the assembly of separate parts of the future product will be successful.

The stage of implementation and compliance with standardisation in the development of armaments occupies a key place in ensuring compliance with security measures. In particular, weapons and ammunition are used in certain conditions not only by the armed forces, but also by law enforcement agencies, private security organisations, collectors, etc. Legislative provision for the standardisation of the development of armaments and military equipment (hereinafter - the AME) is a public activity of the relevant bodies, which affects the creation of products and tools for the defence industry through regulations.

Five European countries, France, Italy, the Netherlands, Belgium and Luxembourg, were the first to decide to standardize armaments by forming the FINBEL group in 1953 (Burigana and Deloge, 2006). FINBEL group had succeeded in standardization of spare parts, but not for finished products (Alla and Sergii, 2021). Also created regional organizations of a small amount of cooperation: Union of South American Nations (UNASUR), Association of Southeast Asian Nations (ASEAN), Shanghai Cooperation Organization (SCO), Economic Community of West Africa (ECOWAS), Southern African Development Community (SADC), African Union (AU). In turn, groups with great military capabilities made up the following groups of: North Atlantic Treaty Organization (NATO), Commonwealth of Independent States (CIS), European Union (EU) (Alla and Sergii, 2021).

Standardisation of military equipment is an integral part of the system, which is called "standardisation in the defence sector". Armament's standardisation is a method of improving interoperability within the country and between the armed forces, a process that can lead to cost savings in defence development and increase the operational efficiency of military personnel (European Union Institute for Security Search, 2018). At the same time, military standardisation activities in the defence sector result in a creation of a group, a complex and a certain system of standards.

Modern administrative and legal support for defence standardisation in foreign countries, NATO and the EU is a major factor in the establishment and operation of defence standardisation systems and directly affects the protection of sovereignty, territorial integrity and security, protection of society and states that are part of international and regional defence organisations from internal and external threats (Podoinitsyn, 2019). 
Demian V. Smernytskyi, Mykhailo Y. Aleksandrov, Vadym I. Prykhodko, Valerï M.

Podoinitsyn y Malvina A. Bakal

Legislative Provision of Standardisation of Armaments and Military Equipment Development:

Ukraine's thrive for global economic integration necessitates bringing the national system of standardisation and technical regulation in line with the principles of the World Trade Organisation (hereinafter - the WTO), in particular, the Agreement on Technical Barriers to Trade (hereinafter - the TBT Agreement) (State Committee of Ukraine on Technical Regulation and Consumer Policy, 2006).

In many developing countries, there are companies that produced weapons designed during the Soviet era, including ammunition, for several years. But, countries that decided to start producing ammunition in compliance with NATO standards have already set up export promotion councils to attract other countries to process, modernise and expand their product range (King, 2010).

In order to investigate the topic of article the aim of the study became to identify objectives and measures for expansion of the system of standards in the context of improving national defence capabilities.

The study will contribute to further progress of the national system of standards for the development of armaments and military equipment, taking into account the experience of other countries, which will promote effective management of this process, making optimal technical decisions, minimising state budget costs in developing defence products.

The topicality of the study is that the results of the work of the Ministry of Defence and other central executive bodies on the application of the system of standards by domestic enterprises indicate the need for its radical change or the creation of a new one (Cabinet of Ministers of Ukraine, 2009). In addition, a clear idea of the scope and structure of the system of legislation to standardise the development of armaments and military equipment is extremely important in times of armed aggression by the Russian Federation against Ukraine (Verkhovna Rada of Ukraine, 2018). A logically designed system of defence standards will further implement NATO and NATO member states' defence standards (Verkhovna Rada of Ukraine, 2019), increase the level of conformity of developed weapons with modern conditions of hostilities in eastern Ukraine, and thus strengthen the level of security at state borders and increase the prestige of the Armed Forces as a whole.

In the scientific literature one can find attempts to study the legislative provision of national defence product standardisation. However, despite the large number of available texts, little attention is paid to the issue of determining the scope of activities and existing AME standardisation Programmes.

A group of scholars studied the practical implementation of military standards. 
Aim of the research is identification of ways, main objectives, and regulatory measures for further advance of the national system of standards for AME development in the context of improving national defence capabilities.

Research objectives are the following:

- Determine the essence and composition of the standardisation system of AME development.

- Determine the bodies responsible for the implementation of legislative support for AME standardisation.

- Analyse the foreign experience of administrative implementation of AME standardisation.

- Formulate proposals to increase the efficiency of legislative support for AME standardisation.

\section{Literature Review}

The study, analysis, generalisation, and systematisation of empirical developments in the scientific literature on the AME standardisation in the context of administrative law, allowed us to provide basic opinions that are important for this article. Namely:

1. Since the development of high-precision AME leads to the need to create a new generation of specialised control systems, their characteristics and parameters during testing, the primary need is to improve the test system, the regulatory framework of which is a system of standards.

As a result of the practice, the period of updating (glancing) of the standards in the middle warehouse is 5 years. For the rest of the rock, there have been changes in the minds of the growth of intelligence in military equipment, the accumulation of significant information about the robots with the existing system of standards in defense halls, the meaning of the changes and inadequacies of the new generation of standards (Lappo et al., 2020).

2. Arms standardisation within a military alliance has a number of advantages. This ensures the division of arms production into separate coalition territories, which facilitate supplies in the event of a conflict. It also increases the cost-effectiveness of production and science by combining efforts of research agencies (Akşit, 2014). It also facilitates interaction between allied countries and the maintenance of units during war, allowing to join and exchange ammunition, spare parts, and so on (Raflik, 2016). 
Demian V. Smernytskyi, Mykhailo Y. Aleksandrov, Vadym I. Prykhodko, Valerï M.

Podoinitsyn y Malvina A. Bakal

Legislative Provision of Standardisation of Armaments and Military Equipment Development:

3. The success of the development of new technologies and AME is closely linked to the full cycle of theoretical and practical research, laboratory, and field tests. This, in turn, requires the creation or modernisation of appropriate material and technical resources as well as testing facilities, bringing it to the current technical level, which requires significant financial and material costs (Lappo et al., 2020).

4. NATO standardisation supports the achievement and strengthening of interaction between NATO forces and allied forces to strengthen defence capabilities and operational capabilities. Standardisation for achieving compatibility is not an end in itself but is a key factor. NATO standardisation is the development and implementation of procedures, projects and terms to the level required for interaction between the Allies, or recommendations on good practice. To achieve interoperability, standardisation requires a comprehensive and systemic approach, starting with the definition of requirements, followed by the development of solutions, their implementation and verification (NATO Standardisation Office, 2018). Reforming the military and security sectors in line with NATO standards is a priority for Ukraine (Mission of Ukraine to the North Atlantic Treaty Organisation, 2021).

5. The Ukrainian way of applying NATO standards has a positive dynamic, but often public discourse causes problems with the interpretation of basic concepts. There is still a lot of work ahead, as most standards have not yet been adopted (Kozii and Tarasiuk, 2019).

6. Woznyak et al. (2016) found that in recent years more than seventy countries of the Alliance at various levels (Partnership for Peace, Mediterranean Dialogue, Istanbul Cooperation Initiative, etc.) have shown interest in the Alliance's standardisation policy.

There are many reasons for this interest, the main of which are the partners' thrive to increase the level of national security through integration into a democratic community and saving their own resources and efforts. Thus, standardisation is a topical issue for both the Alliance and all its members and partners (Ministry of Defence and Veterans Affairs of France, 2011)

7. In the United States, there are no federal rules on the safety standards of firearms produced. Federal law does not establish any safety standards for the design of domestic firearms. This is because, unlike any other consumer product made in the United States, firearms and ammunition are not subject to the health and safety standards set by the Federal Consumer Safety Act. As a result, many types of firearms 
are manufactured and sold in the United States without proper security testing and without the inclusion of basic security features (Giffords Law Centre, n. d.).

\section{Methodology}

The input data for this study were information obtained from scientific papers (Johannes, 2018; King, 2010; Lappo et al., 2020) and articles (Eurolab, 2017; European Union Institute for Security Search, 2018; Ukrinform, 2021). In this case, the main empirical background of the study is collected using four methods: direct observation, comparison, monitoring and analysis of the documents, which ensure the standardisation of armament and military equipment at the state and interstate levels.

It was established in the course of direct observation that the role of legislative support is not limited to the establishment and enshrinement of technical requirements in regulations. The importance of regulation also lies in identification of bodies and organisations responsible for the implementation of standards, the distribution of functions between them, as well as identification of the limits of liability for non-compliance with the legal requirements set forth in engineering requirements. In addition, Ukraine's course towards association with the EU and the alliance of NATO member states is a promising direction for changing the current system of standardisation of AME development.

When using the method of comparison, the laws, documents, and regulations governing the standards of AME development were identified, the legal background for the standardisation of AME development was determined, and the life cycle of the AME models was formed.

It is established that the standardisation system will not function fully, have gaps and uncertainties without proper financial and legislative support. In addition, it was found that no NATO member country has yet implemented all existing Alliance standards.

The monitoring revealed that the regulatory framework needs to be improved in terms of the procedure for establishing, substantiating, and controlling standardisation requirements. It was established that, in addition to the NATO alliance, there are many other international armaments standardisation Programmes under the agreements reached.

During the analysis of the content of various documents, the information posted on social networks and news websites was studied. The current scope and sources governing the standardisation of AME development was established. In addition, the tendencies of standardisation in the world, objectives and directions of legislative regulation of standardisation are investigated. 
Demian V. Smernytskyi, Mykhailo Y. Aleksandrov, Vadym I. Prykhodko, Valerï M.

Podoinitsyn y Malvina A. Bakal

Legislative Provision of Standardisation of Armaments and Military Equipment Development: International Aspect

\section{Results}

Armaments are a set of military weapons, ammunition and technical facilities that ensure their use. Military equipment is technical facilities designed to ensure and conduct hostilities, train personnel, as well as to ensure a given degree of readiness for the use of weapons and such facilities. The AME development is a stage that consists of designing, manufacturing and testing prototypes needed to test selected technical solutions (Ukrainian Research and Training Centre of Standardisation, Certification and Quality, n. d.).

The existing legal framework needs to be improved in terms of the procedure for establishing, justifying and controlling the requirements for standardisation and unification of advanced armaments systems and AME models. This is especially true for single or small-scale production of complex armaments systems and AME which are created using imported components, electronic component base, electrical radio products, software and algorithms (Kulagin, 2009).

In this regard, Law No. 2742-VIII introduced military standardisation. It should aim to ensure maximum interoperability between the Ministry of Defence, the General Staff of the Armed Forces, other military units, law enforcement agencies, central and other executive bodies in the field of defence, as well as with armed forces of the North Atlantic Treaty Organisations and forces of NATO member states through military standards. Military standards cover standards intended for administrative (management processes, information exchange, documentation procedures, etc.) and operational (military practice, operational planning, methods, procedures, etc.) defence objectives, and all, without exception, NATO standards and defence standards of NATO member states (Ministry of Economy of Ukraine, 2019).

By definition, a standard is a regulatory document based on consensus, adopted by a recognised body, which establishes rules, guidelines or characteristics of the activity or its results for general and repeated use, and aims to achieve the optimal degree of order in a particular area (Verkhovna Rada of Ukraine, 2014). Military standard is a standard adopted by the military standardisation body, which establishes rules and guidelines for activities in the defence sector for general and repeated use and is aimed at achieving the optimal degree of regulation in this area (Verkhovna Rada of Ukraine, 1992a).

Public law requires the Minister of Defence to have the highest level of standardisation of the Ministry's tools used by developing and using uniform specifications, reducing the number, size and types of such defence items. The library of unique military specifications, standards and reference books is one of the important tools used by the Ministry of Defence to acquire 
and maintain its armaments systems. Military specifications, standards and reference books are crucial for the Ministry of Defence, as they provide the basis for meeting unique military needs at a cost-effective price while maximizing competition. Ongoing development, indexing and maintenance of these documents provide the needs of the Ministry of Defence in terms of time and costs (Defence standardisation Programme office, n. d.).

Yesimov and Dutuyk (2017) is also right that in order to accelerate the development of mechanisms that promote the implementation of the Association Agreement between Ukraine and the EU and increase the level of national security and defence capabilities of the state, it is necessary to explore priorities, trends, strategic goals, objectives, principles and directions of legal regulation of standardisation.

Formally, the legal background of the state standardisation system in the field of armaments and military equipment are: current legislation (Ministry of Economy of Ukraine, 2019), current regulations (Presidential Decrees, Government Resolutions, Orders of the Minister of Defence), the Concept of National Standardisation System to Create a National System for Developing and Supplying Armaments, Military and Special Equipment (Cabinet of Ministers of Ukraine, 2009), system of current standards, classifiers, targeted standardisation Programmemes by types of AME, international treaties, etc. Besides, the organisational principles of military standardisation are determined by the Resolution of the Cabinet of Ministers of Ukraine (1993) "On the Organisation of Work on Standardisation of Armaments and Military Equipment in Ukraine", "Regulations on Military Standardisation" approved by Order of the Minister of Defence of Ukraine No. 56 of 24.02.2020, which will regulate the process of implementation of NATO standards and guidelines within the security and defence sector of Ukraine (Ministry of Defence of Ukraine, 2020a), the Programme of Work on Military Standardisation for 2021 - 2023 approved by the Order of the Head of Standardisation, Codification and Cataloguing No. 80 of 30.12.2020 (Ministry of Defence of Ukraine, 2020b). At the same time, for better perception, it is proposed to schematically present the whole set of regulatory documents on standardisation of AME development in Figure 1 (Legal framework for standardisation of AME development).

To ensure the development of national standardisation, its compliance with the requirements of the Technical Barriers to Trade Agreement of the World Trade Organisation and harmonisation with the European standardisation model, the Programmeme of Revision of Current Interstate Standards (GOST) Developed in Ukraine before 1992, and Bringing them in Line with the Technical Barriers to Trade Agreement of the World Trade Organisation was adopted (State Committee of Ukraine on Technical Regulation and Consumer Policy, 2006). 
Demian V. Smernytskyi, Mykhailo Y. Aleksandrov, Vadym I. Prykhodko, Valerii M.

Podoinitsyn y Malvina A. Bakal

90

Legislative Provision of Standardisation of Armaments and Military Equipment Development:

International Aspect

At the same time, the system of documents on standardisation of armaments and military equipment is still represented both by the relevant standards of the former USSR in the military sphere, and standards adopted by the Ministry of Defence of Ukraine and the State Enterprise "Ukrainian Research and Training Centre for Standardisation, Certification and Quality" SE “UkrNDNC").

At the same time, in accordance with the agreement between the CIS countries "On the Organisation of Interstate Standardisation of Armaments and Military Equipment" of 03.11.1995, the work on interstate standardisation of armaments and military equipment will be carried out without harming the national interests of Ukraine (Verkhovna Rada of Ukraine, 1992b). However, this agreement is currently suspended (Cabinet of Ministers of Ukraine, 2019).

Podoinitsyn and Yafonkin (2017) note that the role of law is not reduced to the establishment and consolidation of technical requirements should be taken into account when considering the issue of legal regulation of standardisation. The legal regulation is also important because of the impact on the behaviour of individuals in society, which would ensure the implementation and compliance with technical requirements enshrined in the legal regulations. This is achieved by: establishing a general procedure for acceptance of raw materials and finished products of a certain level of quality; regulation of relations arising in connection with the use of measuring equipment; bringing to legal responsibility in connection with violation of regulations and metrological rules; regulation of relations regarding the quality of products and services. 


\section{LEGAL FRAMEWORK FOR STANDARTISATION OF AME DEVELOPMENT \\ Laws of Ukraine: \\ "On Standardisation"; "On Defence of Ukraine"; "On Metrology and Metrological Activity"; "On State Defence Order"; "On Technical Regulations and Conformity Assessments"; "On Amendments to Certain Laws of Ukraine on Military Standards".}

\section{Regulatory acts}

Resolution of the Cabinet of Ministers of Ukraine "On the Organisation of Work on the Standardisation of Armaments and Military Equipment in Ukraine" No. 662 of 19.08.1993;

Resolution of the Cabinet of Ministers of Ukraine "Issues of the State Defence Order" No. 464 of April 27, 2011;

Concept of the National System of Standardisation of the Creation of a National System of Development and Supply of Armaments, Military and Special Equipment, Approved by the Order of the Cabinet of Ministers No. 756-r of 01.07.2009;

Regulations on Military Standardisation Approved by Order of the Ministry of Internal Affairs No. 56 of 24.02 .2020 ;

Order of the Ministry of Internal Affairs "On Approval of the Regulations on Standardisation in the Ministry of Defence of Ukraine and the Armed Forces of Ukraine" No. 655 of 02.12.2016;

Order of the Ministry of Internal Affairs "On Ensuring the Functioning of the Military Standardisation System" No. 670 of 26.12 .2019 .

Order of the Ministry of Internal Affairs "On Approval of the Regulations on the Office of Standardisation, Codification and Cataloguing" No. 272 of 10.08.2020;

KND B 50-053-95. Guiding regulatory document on standardisation of armaments and military equipment. "Regulations on the State Fund of Regulatory Documentation on Armaments and Military Equipment" approved by the Order of the State Committee for Technical Regulation and Consumer Policy of Ukraine No. 3 of 24.07 .1995 ;

Decree of the President of Ukraine "On the Regulations on the Ministry of Defence of Ukraine and the Regulations on the General Staff of the Armed Forces of Ukraine" No. 406/2011 of 06.04.2011;

\section{System of national standards:}

standards of the former USSR that have not expired;

standards adopted by the Ministry of Defence of Ukraine;

standards and programmes adopted by SE "UkrNDNC";

standards adopted by the Institute of Standardisation under SE "UkrNDNC"

System of International Standards

NATO International Standardisation Agreement (STANAGs));

NATO Allied Publication on Standardisation (APs) (NATO standard is an annex);

NATO Standardisation Recommendations (STANREC) (NATO standard is an annex);

International documents:

International Agreement between the CIS countries "On the Organisation of Interstate Standardisation of Armaments and Military Equipment" of 03.11.1995

Directive for the Production, Maintenance and Management of NATO Standardisation Documents

\section{Figure 1: Legal Framework for Standardisation of AME Development.}


Demian V. Smernytskyi, Mykhailo Y. Aleksandrov, Vadym I. Prykhodko, Valerii M.

Podoinitsyn y Malvina A. Bakal

According to the legislation of Ukraine, the standards are of a recommendatory nature and are applied on a voluntary basis. The powers of central executive bodies are determined by the Constitution and laws of Ukraine (Cabinet of Ministers of Ukraine, 2009).

Standardisation procedure includes: development, preparation, production and updating of standardisation documents (Bumgardner, 2010). In total, there are about 1,160 standards and related standardisation guidelines in the NATO Standardisation Documents Database (NSDD) (2021). In addition, national regulations for defence products are:

a) national standards for defence products;

b) national codes of good practice for defence products;

c) national standards for defence products for a particular period;

d) military supplements to national standards;

e) military supplements to national standards for a special period;

f) military supplements to national standards for defence products for a particular period.

In addition, the national regulations include a trial standard. This is a document that has been temporarily adopted by the standardisation body and brought to a wide range of users to gain the necessary experience during its application, for the basic standard to be based on (Figure 1).

NATO's standards system is integrated into a complex system of standardisation regulations. The NATO Allied Publications (AP) is a document that sets the standard itself and is intended for direct application by the military authorities of NATO member states, particular organisations and units (Getmachuk et al., 2019).

Major NATO publications on standardisation include:

- AAR-3 standardisation procedures (Production, Maintenance and Management of NATO Standardisation Documents).

- Register of agreements and publications on standardisation AAP-4 (NATO Standardisation Agreements and Allied Publications).

- AAP-6 Glossary (NATO Glossary of Terms and Definitions).

- List of accepted abbreviations AAP-15 (Glossary of Abbreviations Used in NATO Documents).

The NATO Standardisation Agreement (STANAGs) is an international treaty that regulates the general rules and procedures, the unification of administrative, technical, and logistic processes, armaments and military equipment, as well as other material assets of Allied and Partner Countries. 
Standardisation agreements also define the criteria for interoperability between Member States and partners (Kozii and Tarasiuk, 2019).

SRD - other documents related to NATO standards (Getmachuk and Fakhurdinova, 2021).

The NATO standards can best be formulated by multinational teams of national experts (North Atlantic Treaty Organisation (NATO), 1997).

The Ministry of Defence of Ukraine (n. d.) provides for the following measures to implement NATO standards:

- identification of lists of NATO standards by areas of activity (defence standards of NATO member states), their priorities.

- requesting and obtaining certain NATO standards (defence standards of NATO member states).

- study and elaboration of NATO standards (defence standards of NATO member states), their translation (if necessary), decisionmaking on the application of their provisions (norms, requirements) in the Armed Forces of Ukraine and other components of the security and defence sector.

- submission of proposals to the national standardisation body for adoption of international and regional standards as national standards in case of reference to them in international military standards.

- development of relevant regulations or documents on military standardisation (amendments to existing ones) on the basis of NATO standards (defence standards of NATO member states).

Figure 2 shows that the stage of implementation of material standards by the state, which is still carried out by many NATO countries, as well as Ukraine, is only one of the eight other necessary steps towards their mutual interstate coordination. We should not forget about the conditions of STANAG implementation under the conditions of a pandemic (Campbell, 2020). 
Demian V. Smernytskyi, Mykhailo Y. Aleksandrov, Vadym I. Prykhodko, Valerii M. Podoinitsyn y Malvina A. Bakal

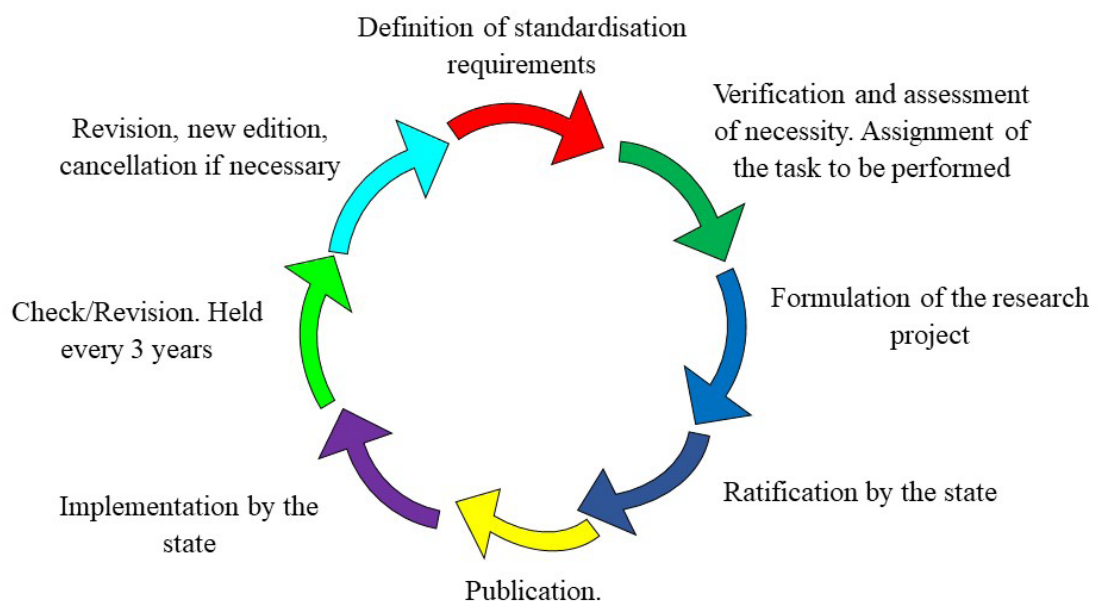

Distribution of final provisions

\section{Figure 2: Lifecycle of STANAG Standards}

On this issue, the enterprises of State Concern "Ukroboronprom" selected 300 NATO material standards (STANAG), which associated with the AME production in 2017, based on the results of elaboration of the entire list of NATO standards in order to determine the feasibility of their implementation in Ukraine as national standards - DSTU V.

The powers of executive and supervisory bodies for the development and implementation of AME standards are distributed as follows:

- SE "UkrNDNC" - conducts active work on the implementation and coordination of activities for the development, adoption, verification, revision, cancellation and renewal of standards;

- The Institute of Standardisation, which is a part of UkrNDNC, is the leading organisation of Ukraine in scientific and methodological management of development, implementation and operation of national standardisation, as well as the main organisation in Ukraine for standardisation of armaments and military equipment. In particular, 205 relevant standards have been adopted for military equipment (Cabinet of Ministers of Ukraine, 2009).

- The Department of Standardisation, Codification and Cataloguing of the Ministry of Defence performs tasks related to the legal regulation of relations in the field of military standardisation, cancellation, renewal, publication, introduction and application of military 
standards, organisation and control over the standardisation of products (Ministry of Defence of Ukraine, 2020c).

- The Minister of Defence is responsible for the implementation of military standards.

- The Standardisation Commission is the leading supervisory body for standardisation, which is responsible for coordinating the activities of military authorities on the adoption and implementation of provisions (norms, requirements) of international military regulations and reconciliation of discrepancies that may arise when approving draft military standards, distributing responsibility for developing NATO standards, etc.

- Technical Committee for Standardisation 176 - conducts work on material (technical) standardisation, usually as part of national standardisation through defence products.

- Military standardisation organisations (scientific and research institutions) and temporary (joint) working groups develop, verify and timely revise military standards in accordance with the areas of work or under particular tasks (Getmachuk et al., 2019).

Given the above, taking into account the terms and concepts of DSTU V 8821-1 2018, I propose to schematically present the lifecycle of AME (Figure 3). This figure shows the sequential and logical place of the stage of standardisation of AME development, namely: after setting the terms of reference, taking into account the standards for development and before production (manufacture, testing and creation) of AME.

In addition, the Cabinet of Ministers of Ukraine should establish a central executive body - Defence Technology Development Agency - by the end of June 2021 as part of the reform of the defence industry in order to implement an effective system of organisation and research on innovative defence technologies (hereinafter - DT) for the development of high-tech armaments on their basis.

However, there are obstacles and challenges in implementing NATO (1997) standards:

- Confusion in terms. In Ukraine, the term "standard" applies not only to military standards of NATO or NATO member states, but also to norms, principles and practices of the Alliance or its member states, which is not entirely correct;

- Insufficient number of professionals with the appropriate level of language involved in the process of developing NATO standards; 


\section{Demian V. Smernytskyi, Mykhailo Y. Aleksandrov, Vadym I. Prykhodko, Valerï M. \\ Podoinitsyn y Malvina A. Bakal \\ Legislative Provision of Standardisation of Armaments and Military Equipment Development:}

- Irrational use of human resources. Leading positions are mostly held by representatives of the "old cohort";

- The need for significant investment in the application of NATO material standards.

Some Eastern European countries, such as the Czech Republic and Poland, have made progress in standardising NATO by developing modern small arms of the NATO-approved calibre, but the transition to those small arms and qualified NATO ammunitions designs depends on the funding provided. More importantly, the US Army's 2014 Military Weapons Strategy showed that Americans are considering non-NATO calibres for new rifles and machine guns. The army's strategy stated that imminent threats prompted the development of a common, intermediate calibre to maximise firepower and efficiency for the unit, while having vulnerability and accuracy at all distances.

Past NATO experience has also shown that when the alliance switched to new weapons, the level of standardisation was generally maintained due to the availability of adequate funding and resources. From a practical point of view, it was not advantageous to introduce interchange ability of calibres, such as $5.56 \mathrm{~mm}$, because the members of the alliance would have to further ratify the existing STANAG. At the same time, the alliance must always be ready to improve the standardisation of ammunition for the intermediate calibre to emerge (Zhou, 2016).

On paper, NATO is an ideal organisation that sets standards for the use of artificial intelligence for military purposes, but this may be hampered by the priorities and budgets of its 30 members (Heikkilä, 2021).

In addition to NATO, there are many other international armaments standardisation Programmes under the agreements. As a result, for some countries, the system of regulatory documents for AME standardisation is somewhat broader than the national one.

AME lifecycle is shown on Figure 3. 


\begin{tabular}{|c|}
\hline Stage of "design" of the product \\
\hline $\begin{array}{l}\text { The period of planning and justification of the need, possibility } \\
\text { and feasibility of AME development }\end{array}$ \\
\hline $\begin{array}{c}\text { Terms of reference, taking into account the standards for AME } \\
\text { developmentr } 4\end{array}$ \\
\hline $\begin{array}{l}\text { Development stage - the time from the adoption of the decision } \\
\text { on the creation of a product until the completion of the } \\
\text { adjustment of technological documentation. It consists of: } \\
\text { design, manufacture and testing of prototypes. }\end{array}$ \\
\hline$\downarrow$ \\
\hline Production (manufacture, testing and creation) \\
\hline$\downarrow$ \\
\hline Acceptance and delivery of the manufactured AME to the troops \\
\hline$\downarrow$ \\
\hline Period of effective life of AME (operation period) \\
\hline$\downarrow$ \\
\hline Overhaul and partial modification of AME \\
\hline$\downarrow$ \\
\hline Report on the results of practical use \\
\hline 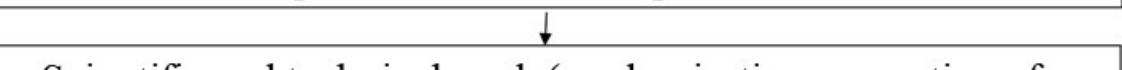 \\
\hline $\begin{array}{c}\text { Scientific and technical work (modernisation or creation of a } \\
\text { new model of AME, new substances or materials) }\end{array}$ \\
\hline
\end{tabular}

Figure 3: AME Lifecycle

United States (AUSCANNZUKUS). The AUSCANNZUKUS grouping is to facilitate the exchange of knowledge, which enables the serviceman to successfully complete missions in the full range of joint and combined operations. The Network's working groups cover the concepts of operations, standard operating procedures, and technical operating instructions. 
Demian V. Smernytskyi, Mykhailo Y. Aleksandrov, Vadym I. Prykhodko, Valerï M.

Podoinitsyn y Malvina A. Bakal

98

International Aspect

The Combined Communications-Electronics Board (CCEB). CCEB is the five national joint military communications and electronics organisations (C-E) with the mission to coordinate any C-E military case transferred to it by a Member State. CCEB member states are Australia, Canada, New Zealand, the United Kingdom, and the United States (Defence standardisation Programme, n. d.).

In addition, during a briefing on March 16, 2020, the press secretary of the Minister of Defence of Ukraine S. Pavlovska said that the Ministry of Defence of Ukraine is putting all efforts to ensure that the Armed Forces of Ukraine are as compatible as possible with the forces of NATO member states. The Ministry has established standardisation, codification, and cataloguing departments in order to achieve this goal and interoperability between Ukraine's defence forces and NATO member states (UANATO, 2020).

'Ukraine is creating a national system of transition to the NATO standard. Deputy Prime Minister for European and Euro-Atlantic Integration Olga Stefanyshyna announced the launch of such a system on April 6. Ukraine is firmly moving towards accession; NATO is the only way to end the war in eastern Ukraine.' Shmygal wrote on his Facebook page (Ukrinform, 2021).

Valery Chaly, Chairman of the Board of the Ukrainian Crisis Media Centre, emphasised that NATO membership is a strategic direction of Ukraine's foreign policy. The Alliance, seen as a key game in Europe's fortified defence and security, is a benchmark for Ukraine, and the status of its member is a goal. "The constitution provides a clear background for future accession and membership strategies. However, it is important to remember that there is still a lot to do on the way, this is a homework for Ukraine', Valerii Chalyi said (Ukraine Crisis Media Centre, 2021).

Although NATO helps to limit the scope of standardisation, security aspects and the enormous size of the alliance make it a cumbersome grouping to achieve technical harmonisation of armaments. The ABCANZ group of countries is becoming a key factor in setting technical standards, which will also help influence NATO (Johannes, 2018).

In the long run, cooperation between NATO and a certain country without mutual commitments requires the first level of standardisation (compatibility), partnership with mutual assistance commitments requires the second level (interchange ability), and the country's integration into NATO requires the third level of standardisation (unification) (Woznyak et al., 2016). As of January 2021, Ukraine has implemented a total of 292 NATO standards and guidelines (about 19\% of standardisation agreements), of which 86 are substantive standards (Getmachuk and Fakhurdinova, 2021). This is $27 \%$ of the implemented standards and $14 \%$ of the total number of NATO material standards. 
Moreover, since June 12, 2020, Ukraine has been one of the six countries (known as Enhanced Opportunities Partners under the Partnership Initiative) that make a particularly significant contribution to NATO operations and other NATO objectives. Thus, the country has expanded opportunities for dialogue and cooperation with allies (North Atlantic Treaty Organisation (NATO), 2021).

\section{Discussion}

Administrative and legal support for defence standardisation is not only a key factor in the effective functioning of standardisation systems, which affects the protection of sovereignty, territorial integrity and security of the state from internal and external threats (Podoinitsyn, 2019), it is also appropriate to keep in mind that this is an ongoing process for many NATO countries (Zhou, 2016), as well as other international defence groups (Heikkilä, 2021). It should be noted that obstacles to the implementation of STANAG standards become even greater (NATO, 1997), and the implementation process itself is delayed under the conditions of a pandemic (Campbell, 2020).

The development stage, which involves the design, manufacture and testing of prototypes, occupies an important place in the AME lifecycle. Adoption of STANAG material standards at the interstate level and at the level of the Ministry of Defence of Ukraine is still a long stage, inspection and revision can take place every 3 years (Figure 2).

Despitethefact that the system of currentlevels of militarystandardisation is fully consistent with the system of NATO countries (Cabinet of Ministers of Ukraine, 1993), work on material (technical) standardisation should be further carried out by TC 176 .

The advantages of standardisation cannot be overestimated, in particular, it: ensures the establishment of mass production; improves coordination with suppliers; improves product quality; allows to simplify production process of necessary products and means; reduces the excessive accumulation of spare parts and components (AsqNotes, 2021).

The fundamental role of the North Atlantic Alliance is to protect the freedom and security of member countries by political and military means. The U.S. Code states that U.S. policy provides that equipment purchased for U.S. forces used in Europe under the terms of the North Atlantic Treaty should be standardised to the level or extent necessary to interact with equipment used by other NATO members for similar purposes (Campbell, 2020). For its part, the Alliance will play an active role in strengthening international security, in partnership with relevant countries and other 
Demian V. Smernytskyi, Mykhailo Y. Aleksandrov, Vadym I. Prykhodko, Valerii M.

Podoinitsyn y Malvina A. Bakal

100

Legislative Provision of Standardisation of Armaments and Military Equipment Development:

international organisations, keeping the door to NATO membership open to all European democracies that meet North Atlantic Treaty Organisation (NATO) (2010) standards.

In international aspect order to be able to integrate into NATO on an equal partnership basis, Ukraine means to implement the Alliance's positive experience of administrative and legal support for defence standardisation. That will allow it to effectively develop and implement concepts, doctrines, procedures and projects to achieve and maintain interoperability, as well as for optimisation, use of resources for operational, technical and administrative purposes. Modern administrative and legal support for defence standardisation in foreign countries, NATO and the EU is a major factor in the establishment and operation of defence standardisation systems, and directly affects the protection of sovereignty, territorial integrity and security, protection of society and states that are members if international and regional defence organisations, from internal and external threats (Podoinitsyn, 2019).

We propose the following to increase the effectiveness of legislative support for AME standardisation:

- Intensification of exchange of experience and information between Ukraine and NATO and EU countries on the implementation of STANAG;

- Modernisation of the existing system of standardisation in the field of defence industry and updating of standards to modern requirements for the Armed Forces of Ukraine;

- Complete replacement of the standards of the former USSR with domestic standards and armament standards STANAG;

- In order to comply with a single concept of implementation of standards and prioritisation of regulations, apply the scheme of the regulatory system of standards (Figure 1);

- implementation of new NATO standards by republishing (revision, translation).

\section{Conclusions}

Defence requirements are becoming increasingly complex, and frequent organisational changes and rapidly evolving technological advances can lead to inadequate compatibility of AME at both the national and international levels. Inconsistencies in capability planning and management, without a proper defence standardisation system, can contribute to duplication, reinvention, increased costs and time, and reduce the military effectiveness 
of AME. In addition, the harmonisation of defence standards applied in the defence sector is a key factor in the interoperability of military equipment used by the armed forces.

In international aspect the method of implementing the standards, including NATO, is correct, the degree of their implementation depends on the amount of funding for this Programmeme and the desire to follow the concept of the national standardisation system. The implementation of the current STANAG standards has a positive dynamics, but is slow. In particular, in the period from 2014 to 2021 , only $14 \%$ of the total list of NATO material standards was implemented. It should also be borne in mind that every 3 years STANAG may be revised and amended. Therefore, the logistical model of material standards of the STANAG alliance of NATO countries, a partner with enhanced capabilities of which is Ukraine, needs faster implementation to the appropriate extent.

The reasons for the slow implementation of AME development standards include: confusion in the terms used in STANAG, insufficient level of language training of those involved in the process of developing NATO standards; holding senior positions in the Ministry of Defence mostly by members of the "old cohort", the need for significant financial costs for the implementation and application of NATO material standards.

Legislative standardisation of AME development is a rather complex ongoing process of development and harmonisation of standards in the defence sector, it requires improvement and clear formal definition of the scope and powers, as well as appropriate financial support of the responsible authorities. Continuous implementation of a modern system of standards will meet the needs of the Ministry of Defence, while saving money and time during the development of weapons. The development and conduct of research according to existing standards should be entrusted to the Agency for Defence Technology Development.

However, the main disadvantage of the implementation of standards in the process of AME development is the burden of additional legal support and administrative control of the supply chain of defence products between both military and civilian suppliers.

Despite the fact that many standards have not yet been adopted, much remains to be done in the future to improve the existing system of legislative support for the standardisation of AME development.

\section{Bibliographic References}

ALLA, Samoilenko; SERGII, Sardak. 2021. Military potential of regional organizations. January 2021. Economic Scope. Available online. In: 
Demian V. Smernytskyi, Mykhailo Y. Aleksandrov, Vadym I. Prykhodko, Valerï M.

Podoinitsyn y Malvina A. Bakal

102

Legislative Provision of Standardisation of Armaments and Military Equipment Development:

International Aspect

https://www.researchgate.net/publication/350303801_MILITARY_ POTENTIAL_OF_REGIONAL_ORGANIZATIONS. Consultation date: 20/03/2021.

AKŞIT, Cihangir. 2014. Smart Standardisation: A Historical and Contemporary Success at NATO. Available online. In: https://www.nato.int/ nato_static/assets/pdf/pdf_2014_05/20140528_140528-smartstandardization.pdf. Consultation date: 14/03/2021.

ASQNOTES. 2021. Defence Standardisation Programmeme. Available online. In: https://acqnotes.com/acqnote/careerfields/defencestandardisation-Programme. Consultation date: 14/03/2021.

BURIGANA, David; DELOGE, Pascal. 2006. Standardisation et production coordonnée des armements en Europe. Une voie vers l'étude d'une défense européenne (1953-2005). In: RUCKER, Katrin, WARLOUZET, Laurent (eds), Quelle(s) Europe(s)? Which Europe(s)? Nouvelles approches en histoire de l'intégration européenne, New Approaches in European Integration History. Peter Lang. Brussels, Belgica.

BUMGARDNER, Sherrod Lewis. 2010. (Eds.). NATO Legal Deskbook, $2^{\text {nd }}$ Edition. Available online. In: https://info. publicintelligence.net/NATOLegalDeskbook.pdf. Consultation date: 14/03/2021.

CABINET OF MINISTERS OF UKRAINE. 1993. Resolution of the Cabinet of Ministers of Ukraine "On the Organisation of Work on the Standardisation of Armaments and Military Equipment in Ukraine". Available online. In: https://zakon.rada.gov.ua/laws/show/662-93-\%Do\%BF\#Text. Consultation date: 14/03/2021.

CABINET OF MINISTERS OF UKRAINE. 2009. The Concept of Creating a National System for the Development and Supply of Weapons, Military and special equipment. Available online. In: https://www.kmu.gov.ua/ npas/227300006. Consultation date: 14/03/2021.

CABINET OF MINISTERS OF UKRAINE. 2019. Resolution of the Cabinet of Ministers of Ukraine "On Termination of the Agreement on Organisation of Work on Interstate Standardisation of Arms and Military Equipment and the Protocol on Amendments and Addenda to the Agreement on Organisation of Work on Interstate Standardisation of Arms and Military Equipment" for Ukraine. Available online. In: https://www.kmu.gov. ua/npas/pro-pripineavnoyi-standartizaciyi-ozbo-organizaciyu-robitshchodo-mizhderzhavnoyi-standartizaciyi-ozbroyennya-i-vijskovoyitehniki. Consultation date: 14/03/2021. 
CAMPBELL, Michael W. 2020. Annual NATO Language Testing Workshop Digitally Connects Record Number of Experts. Available online. In: https://www.marshallcenter.org/de/node/1744. Consultation date: 14/03/2021.

DEFENCE STANDARDISATION PROGRAMME. $\mathrm{n}$. d. International Standardisation. Available online. In: https://www.dsp.dla.mil/ Programmes/International-Standardisation/. Consultation date: 14/03/2021.

DEFENCE STANDARDISATION PROGRAMME OFFICE. n. d. Brochure DSPO. Available online. In: https://www.dsp.dla.mil/ Portals/26/Documents/Publications/160501-Brochure-DSPO. pdf?ver=04PKqQ4ldMsPb9QJfu1WRw\%3d\%3d. Consultation date: 14/03/2021.

EUROLAB. 2017. Mil-std Test and Analysis of Military Standards. Available online. In: https://www.eurolab.com.tr/en/sektorel-test-ve-analizler/ spesifik-testler/mil-std-askeri-standartlarin-test-ve-analizleri. Consultation date: 14/02/2021.

EUROPEAN UNION INSTITUTE FOR SECURITY SEARCH. 2018. European Armaments Standardisation. Available online. In: https://www.iss. europa.eu/content/european-armaments-standardisation Consultation date: $14 / 03 / 2021$.

GETMACHUK, Alyona; ZAREMBO, Kateryna; FAKHURDINOVA, Marianna. 2019. Ukraine and NATO Standards: How to Hit a "Moving Target”? Available online. In: http://neweurope.org.ua/wp-content/ uploads/2019/07/DP_Stand_NATO_eng_inet.pdf. Consultation date: 14/03/2021.

GETMACHUK, Alyona; FAKHURDINOVA, Marianna. 2021. Ukraine and NATO Standards: What Has Been Done during Zelensky's Presidency? Available online. In: http://neweurope.org.ua/wp-content/ uploads/2021/04/FINAL_Ukraine-NATO_Zel_ukr.pdf. Consultation date: $14 / 03 / 2021$.

GIFFORDS LAW CENTRE. n. d. Design Safety Standards. Available online. In: https://giffords.org/lawcenter/gun-laws/policy-areas/child-consumersafety/design-safety-standards/. Consultation date: 14/03/2021.

HEIKKILÄ, Melissa. 2021. NATO Wants to Set AI Standards. If Only Its Members Agreed on the Basics. Available online. In: https://www. politico.eu/article/nato-ai-artificial-intelligence-standards-priorities/. Consultation date: 14/03/2021. 
Demian V. Smernytskyi, Mykhailo Y. Aleksandrov, Vadym I. Prykhodko, Valerï M.

Podoinitsyn y Malvina A. Bakal

104

Legislative Provision of Standardisation of Armaments and Military Equipment Development:

JOHANNES, Maj Chad. 2018. Achieving multinational tactical radio interoperability. Canadian Forces College. Toronto, Canada.

KING, Benjamin. 2010. (Ed.). Surveying Europe's production and procurement of small arms and light weapons ammunition. Small Arms Survey, Graduate Institute of International and Development Studies. Geneva, Switzerland.

KOZII, Ihor; TARASIUK, Taras. 2019. NATO Standards: Implementation Progress in Ukraine. Available online. In: https://rpr.org.ua/en/news/ nato-standards-implementation-progress-in-ukraine/. Consultation date: 14/03/2021.

KULAGIN, Kostiantyn K. 2009. "Features of Standardisation and Unification of Military Technics in Current Conditions Its Development and Manufacture" In: Information Processing Systems. Vol. 6, No. 8o, pp. 61-66.

LAPPO, Iryna M; HERASHCHENKO, Maryna O; CHERVOTOKA, Oleh V. 2020. "Some aspects of NATO standards implementation in the armament and military equipment testing system of Ukraine" In: The Bulletin of the State Research Institute of Testing and Certification of Armaments and Military Equipment. Vol. 2, No. 4, pp. 55-62.

MINISTRY OF DEFENCE AND VETERANS AFFAIRS OF FRANCE. 2011. Instruction related to NATO standardisation within the Ministry of Defence and Veterans Affairs. Ministry of Defence and Veterans Affairs of France. Paris, France.

MINISTRY OF DEFENCE OF UKRAINE. 2020a. Regulations on Military Standardisation. Available online. In: https://zakon.rada.gov.ua/laws/ show/zO240-20\#Text. Consultation date: 14/03/2021.

MINISTRY OF DEFENCE OF UKRAINE. 2020b. Military Standardisation Work Programme For Years 2021-2023. Available online. In: https:// www.mil.gov.ua/content/mil_standard/progr_rob_vs_21_23.pdf. Consultation date: 14/03/2021.

MINISTRY OF DEFENCE OF UKRAINE. 2020c. Order of the Minister of Defence of Ukraine "On Approval of the Regulations on the Management of Standardisation, Codification and Cataloguing". Available online. In: https://www.mil.gov.ua/content/mou_orders/mou_2020/nm_272. pdf. Consultation date: 14/03/2021.

MINISTRY OF DEFENCE OF UKRAINE. n. d. Military Standardisation: Questions and Answers. Available online. In: https://www.mil.gov. ua/diyalnist/vijskova-standartizacziya/zapitannya-i-vidpovidi.html. Consultation date: 14/03/2021. 
MINISTRY OF ECONOMY OF UKRAINE. 2019. Clarifications to The Law of Ukraine "On Amendments to Some Laws of Ukraine on Military Standards" Available online. In: https://www.me.gov. ua/Documents/Detail? lang =uk-UA\&id=546c3682-f5b5-46b5a 8a4-64be461c63cf\&title=RoziasnenniaSchodoZakonuUkra iniVido6-o6-2019-2742-viii-proVnesenniaZminDoDeiakikhZakonivUkrainiSchodoViiskovikhStandartiv-. Consultation date: 14/03/2021.

MISSION OF UKRAINE TO THE NORTH ATLANTIC TREATY ORGANISATION. 2021. Reforming of the Military and Security Sphere in Accordance with NATO Standards is a Priority for Ukraine - Dmytro Razumkov. Available online. In: https://nato.mfa.gov.ua/en/news/ dmitro-razumkov-reformuvannya-vijskovoyi-ta-bezpekovoyi-sferividpovidno-do-standartiv-nato-prioritet-dlya-ukrayini. Consultation date: $14 / 03 / 2021$.

NATO STANDARDISATION DOCUMENTS DATABASE. 2021. List of Current NATO Standards. Available online. In: https://nso.nato.int/nso/nsdd/ listpromulg.html. Consultation date: 14/03/2021.

NATO STANDARDISATION OFFICE. 2018. AAP-O3 Directive for the production, maintenance and management of NATO standardisation documents, edition K, version 1. NATO Standardisation Office. Brussels, Belgium.

NORTH ATLANTIC TREATY ORGANISATION (NATO). 1997. NATO Logistic Handbook. NATO. Brussels, Belgium.

NORTH ATLANTIC TREATY ORGANISATION (NATO). 2010. Active Engagement, Modern Defence. Available online. In: https://www.nato. int/lisbon2010/strategic-concept-2010-eng.pdf. Consultation date: 14/03/2021.

NORTH ATLANTIC TREATY ORGANISATION (NATO). 2021. Relations with Ukraine. Available online. In: https://www.nato.int/cps/en/natolive/ topics_37750.htm. Consultation date: 14/03/2021.

PODOINITSYN, Valerii M. 2019. Legal and Administrative Provision of Standardisation in the sphere of Defence. PhD dissertation thesis abstract. State Research Institute of the Ministry of Internal Affairs of Ukraine. Kyiv, Ukraine.

PODOINITSYN, Valerii M; YAFONKIN, Anatoliy O. 2017. "The concept of legal and administrative provision of standardisation in the sphere of defence" In: International Law Herald: Actual Problems of the Present (Theory and Practice). Vol. 4-5, No 8-9, pp. 51-59. 
Demian V. Smernytskyi, Mykhailo Y. Aleksandrov, Vadym I. Prykhodko, Valerï M.

Podoinitsyn y Malvina A. Bakal

106

International Aspect

RAFLIK, Jenny. 2016. DTIB and the Question of arms Production and Control. Available online. In: https://www.cvce.eu/en/collections/unitcontent/-/unit/56d70f17-5054-49fc-bb9b-5d90735167do/71aaec8763fd-4138-86d6-3b411obf46fa/Resources\# 26doe77f-d5e5-40d1-9344c3793eae325a_en\&overlay. Consultation date: 14/03/2021.

STATE COMMITTEE OF UKRAINE ON TECHNICAL REGULATION AND CONSUMER POLICY. 2006. Programme of Revision of the Interstate Standards in Force in Ukraine (GOST), Developed Before 1992, and Bringing Them in Line with the Agreement on Technical Barriers to Trade of the World Trade Organisation. Available online. In: https:// zakon.rada.gov.ua/rada/show/voo77609-06\#Text. Consultation date: 14/03/2021.

UANATO. 2020. The Ministry of Defence of Ukraine Is Doing Everything Possible to Ensure that the Armed Forces of Ukraine Are as Compatible As Possible with the Forces of NATO Member States. Available online. In: http://uanato.info/index.php?pokaz=10243. Consultation date: 14/03/2021.

UKRAINE CRISIS MEDIA CENTRE. 2021. Why Ukraine Is Still Not a NATO Member: Who Is To Blame and What To Do? Available online. In: https://uacrisis.org/en/why-ukraine-is-still-not-in-nato. Consultation date: 14/03/2021.

UKRAINIANRESEARCHANDTRAININGCENTREOFSTANDARDISATION, CERTIFICATION AND QUALITY. n. d. SE "UkrNDNC" Homepage. Available online. In: http://uas.org.ua. Consultation date: 14/03/2021.

UKRINFORM. 2021. Ukraine Creating National System of Transition to NATO Standards - Shmyhal. Available online. In: https://www.ukrinform. net/rubric-polytics/3225845-ukraine-creating-national-systemof-transition-to-nato-standards-shmyhal.html. Consultation date: 14/03/2021.

VERKHOVNA RADA OF UKRAINE. 1992a. The Law of Ukraine "On Defence of Ukraine”. Available online. In: https://zakon.rada.gov.ua/laws/ show/1932-12\#Text. Consultation date: 14/03/2021.

VERKHOVNA RADA OF UKRAINE. 1992b. Agreement on the Organisation of Work on Interstate Standardisation of Armaments and Military Equipment. Available online. In: https://zakon.rada.gov.ua/laws/ show/997_477\#Text. Consultation date: 14/03/2021.

VERKHOVNA RADA OF UKRAINE. 2014. The Law of Ukraine "On Standardisation”. Available online. In: https://zakon.rada.gov.ua/laws/ 
show/1315-18\#Text. Consultation date: 14/03/2021.

VERKHOVNA RADA OF UKRAINE. 2018. The Resolution of Verkhovna Rada of Ukraine "On a Set of Urgent Measures for the Practical Implementation of the International Legal Responsibility of the Russian Federation for Armed Aggression against Ukraine". Available online. In: https://zakon. rada.gov.ua/laws/show/2356-19\#Text. Consultation date: 14/03/2021.

VERKHOVNA RADA OF UKRAINE. 2019. The Law of Ukraine "On Amendments to Some Laws of Ukraine on Military Standards." Available online. In: https://zakon.rada.gov.ua/laws/show/2742-19\#Text. Consultation date: 14/03/2021.

WOZNYAK, S; IVASCHENKO, A; PENKOVSKY, V. 2016. The North Atlantic Alliance Policy of Standardisation. Available online. In: https://drive. google.com/open?id=1mpEPVTFjy7xeRGiqjHeFwsRvdv5QqDGI. Consultation date: 14/03/2021.

YESIMOV, Serhiy; DUTUYK, Volodymyr. 2017. Administrative-Legal Regulation of Standardisation Is an Important Direction of Improving the Defence of Ukraine. Available online. In: http://science.lpnu.ua/sites/ default/files/journal-paper/2017/aug/580o/vnulpurn2016845111.pdf. Consultation date: 14/03/2021.

ZHOU, Yi Le. 2016. "NATO Infantry Weapons Standardisation: Ideal or Possibility?" Unpublished master's thesis. University of Calgary. Calgary, Canada. 

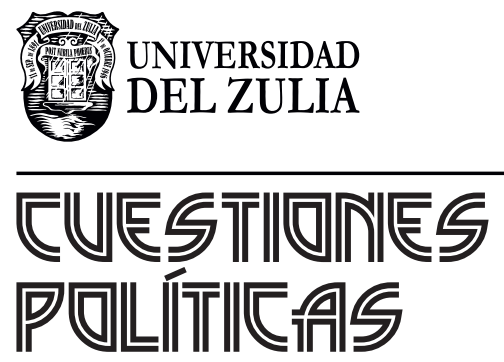

Vol. 39 N $^{\circ} 71$

Esta revista fue editada en formato digital y publicada en diciembre de 2021, por el Fondo Editorial Serbiluz, Universidad del Zulia. Maracaibo-Venezuela 